\title{
A Study on the Development of Jilin Shaman Culture Tourism Products
}

\author{
Hua Jin \\ School of Chang chun Sci-Tech University, Chang Chun 130000, China \\ 57615211@qq.com
}

Keywords: Shaman culture, tourism development, Jilin province, tourism product.

\begin{abstract}
Jilin province is one of the parent source world Shaman culture birthplace, has the world remain relatively intact, Saman culture is rich in content, has a high value of tourism development. Based on the status quo of Shaman culture tourism development in Jilin province were analyzed, based on summarizing the development of Shaman cultural tourism in Jilin Province at the present stage existence on the problems, and puts forward some concrete countermeasures of Shaman culture tourism development.
\end{abstract}

\section{Introduction}

Shamanism as one of the oldest and most influential of the primitive religion of northern China, Manchu shaman religion has the longest history, shaman, shaman ritual shaman, Shaman culture, customs, shaman song of God are preserved, is the precious culture in ancient times "living fossil", is extremely rich in culture the connotation and the unique value of appreciation.. But a Shaman Dance ceremony, ornamental value, language, psychology, memory etc. with the development of modern society and is slowly shrinking weak. Protection consciousness of Shaman culture has been a lot of scholars. The government also established some corresponding protective measures. Reasonable development and use of Shaman culture, and it developed into a distinctive cultural tourism products, not only can achieve rich tourism products in the region, but also to tourism development as an opportunity, will have a strong national characteristics and charm of the Shaman culture pushed to the front of the public.

In recent years, the main development of Jilin province regional tourism products including traditional snow tourism and forest ecotourism in Changbai Mountain line, tourism is the conventional tourism product type. However, with the continuous development of society, the level of tourist cultural quality continues to improve, people demand for tourism products has undergone tremendous changes. Showing a trend of diversification and individuation.First, the main problems in the development of the cultural tourism products in Jilin Province In the selection of travel products, people are more inclined to tourism products and cultural participation, a profound understanding of the historical and cultural tourism products and folk customs, tourism has become an important motivation for many tourists travel. So the design of developers in the development of tourism products, tourism product design, will be to adapt to this change, to explore the unique cultural connotation of the original tourism products, to stabilize the original market, continues to attract new customers to come here for sightseeing, improve the tourists'revisit rate, prolong the life cycle of the tourist destination. Jilin shaman culture is rich in resources, and ecological tourism complement each other, become the fascinating landscape, the better development of the Shaman culture tourism is just to make up for the lack of the characteristics of religious cultural tourism products in Jilin tourism products, enrich the current tourism products. In this way, not only can protect the intangible cultural heritage, but also can enrich the local the tourist resources, shoot two hawks with one arrow. 


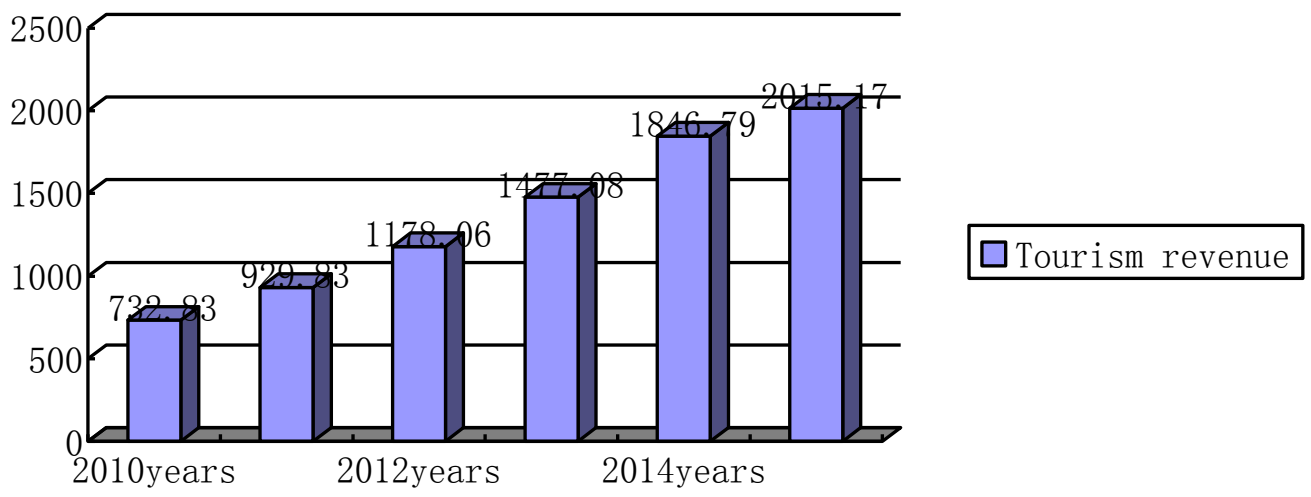

Fig 1. Jilin tourism revenues in 2010-2015 (Units: one hundred million yuan)

Table 1 tourists' understanding of Shamanism culture
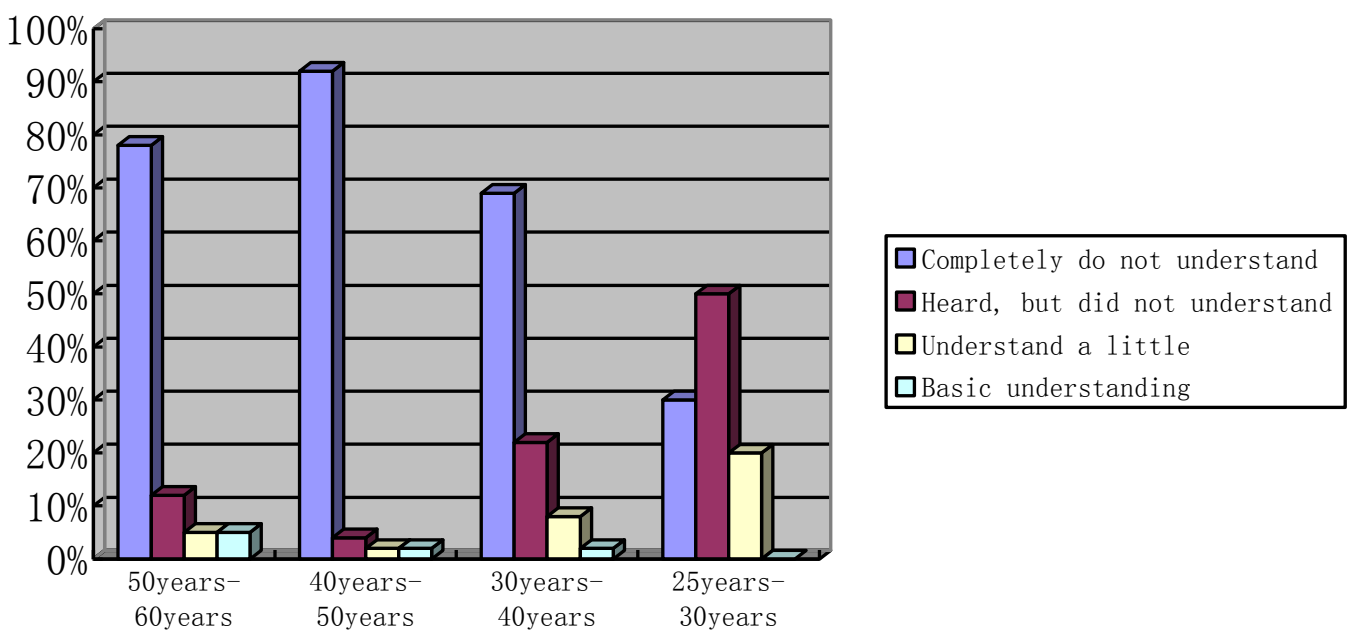

\section{The main problems in the development of the cultural tourism products in Jilin Province}

\subsection{Lack of cultural connotation of tourism products}

In our country, with the primitive religion as the carrier of tourism in the minority, but often appear scenic products, tourism activities related to the status of a mere formality, the lack of participation and experience, plus the area for explaining the cultural carrier, publicity and guidance is not in place, often caused by visitors such as fly travel rush the scenery when feeling. In addition, how many scenic spots show geographical and cultural totem worship and ritual which belongs to religious culture. At present, Jilin Province, the Shaman culture tourist attractions more profit for the purpose, in order to meet the needs of tourists, tourism developers tend to modern art form of Shaman culture packaging exhibition, abandoned the authenticity of the Shaman culture thus, leading to scenic cultural tourism products lack of vitality and competitiveness.media propaganda is not enough, brand building is not strong.

The development of cultural tourism, the breadth and depth are often more dependent on tourism. At present, the traditional tourism development structure of Jilin province tourism natural landscape features still occupy the leading position, will hinder the development and development of the tourism development pattern of Shaman culture tourism. From a practical point of view, Jilin province Shaman culture tourism scenic spot, the basic existence of Shaman culture tourism products less publicity, promotional efforts is not enough. In addition, through the investigation of Jilin province tourist found that many tourism consumers do not understand the Shaman culture tourism products, some do not even know the Jilin Province as well as the characteristic and the world the popularity of Shaman 
culture tourist attractions, but also do not understand the contents and characteristics of Shaman culture tourism products, natural not to participate in the tourism activities.

\subsection{Single form of tourism products}

At present, Jilin province's tourism resources mainly include ice and snow tourism resources, tourism resources, natural tourism resources and cultural tourism resources in four forms. But in the scenic area as the center of the Shaman culture is relatively independent, failed to achieve the scenic area and the surrounding area network, has not formed the scale effect, and the surrounding natural scenery scenic spot is not harmonious collocation lead, comprehensive sensory tourists feel is not strong.

\subsection{The lack of characteristics, the market competitiveness of cultural tourism products}

Shamanism is said to be primitive religious world in ancient times, the development of Jilin province tourism industry started relatively late, and the Shaman culture as human primitive culture already listed as tourism activities. Shaman culture is rich in content, but in the scenic spots are difficult to peep, to dig deep degree and through certain form. Shaman culture in Jilin province tourist attractions are mostly for the purpose of profit, sometimes is not necessarily true culture show. In order to meet the needs of tourists, tourism developers tend to modern art form of Shaman culture for the packaging. In the conflict of economic interests, give up the real Shaman culture connotation, meet the needs of the blind in modern tourism.

\subsection{Lack of professional tourism management professionals}

At present, we are engaged in the service in the majority of front-line personnel are scanty personnel to understand some of the ethnic tourism, so these people in the service when it is very difficult to meet the tourists for deep Shaman culture needs, so whether the relevant departments of tourism management of colleges and universities or colleges of Tourism Management, or tourist attractions, scenic spots should be strengthen the training work of folk tourism management professionals.

\section{The countermeasures for the development of Jilin's cultural tourism products}

\subsection{Innovation product development, improve product culture connotation}

The development of Shaman culture tourism products, not only need to excavate the Shaman culture connotation, prominent characteristics, need to follow the laws of the market, the traditional skills of tourism products transformation, follow the development principle, give visitors a better, more comprehensive acceptance and affirmation of Sa Manwen tourism products.

\subsection{Establishing the cultural tourism ecological museum}

In order to better protect and inherit the culture, should establish cultural eco Museum shaman in Jilin Province, this not to find an important way to protect and inherit the Shaman culture for us, also can let more people understand the Shaman culture, consciously added to the protection and inheritance of the Shaman culture ranks, is a the cultural value into economic value, a new way of tourism value.

\subsection{Highlight the characteristics of the development of fine tourist routes}

The Shaman culture tourism development in Jilin Province, comprehensive planning should be based on the characteristics of folk custom tourist line, based on the grasp of the main line of the Shaman culture on various aspects of the integrated, effective tourism resources and location advantages, to create a Shaman cultural tourism area.

\subsection{Strengthen the training of professional talents}

Strengthen the training of professionals, including not only the folklore tourism management professionals, including training talents. Manchu has very high artistic and cultural shaman shrines of Manchu Shamanism culture, mainly by oral tradition, and mainly in Manchu.

\subsection{Protection and development, adhere to the principle of sustainable development}

At the same time the development of Shaman culture resources must be protected. Both protection and development, adhere to the principles of sustainable development. In the development of Shaman culture tourist resources, should take the overall protection and protection of the principle of 
combining the Shaman culture tourism product planning and product shaping, maximize the excavation of its cultural resources and characteristics the surrounding natural landscape advantages, not only to protect the original form was not damaged, but also to protect its cultural connotation, it embodies the "authentic", formed a complete tourism products.

\subsection{Establish and improve relevant laws}

One is the national laws and regulations as soon as possible suggestions for the protection of intangible cultural heritage. The protection of cultural heritage, depends largely on the relevant laws and regulations in the state and the government. The two is the establishment of protection system and measures of Shaman cultural heritage of the people. The vice chairman of Chinese Minxie, Jilin province ADPL President Cao Baoming proposed to develop protection system and measures of the living cultural heritage of people, should be implemented to proceed. The government of Jilin province should pay protection of living heritage and living site address, to send experts to guide the restoration Shaman culture details and more culture heritage.

\section{Summary}

Shamanism culture in the long course of development, because of its nature, historical limitations in terms of content, has been gradually withdraw from the stage of history. But its unique cultural charm of the shaman but fascinating. According to the development background of the Shaman culture in Jilin province and the existing problems and countermeasures are discussed and analysis, find out the Shaman culture tourism product development strategy of Jilin Province, hoping to make its own contribution to the inheritance and development of Shaman culture.

\section{Acknowledgements}

This research was financially supported by the "Much starker choices-and graver consequencesin"social science research of jilin province department of education (Grant No. [2016] 588 and Grant No.[2016]587).

\section{References}

[1] Su Donghai. The International Eco Museum and the practice of [J]. China movement of Chinese Museum, 2001 (2). Liu Housheng. Study on the Manchu Shamanism divine words thought connotation and artistic charm of national [J].1997 (6)122-135.

[2] Su Donghai. The International Eco Museum and the practice of [J]. China movement of Chinese Museum, 2001 (2)98-125.

[3] The inheritance and development of Shaman culture in modern tourism activities in Jilin province [D]. 1997 (6). Master Thesis of Northeast Normal University, (5)196-225.

[4] Tourism planning [Z]. Jilin Changbai government network (http://www.chang-baishan, gov.cn) 184-205. 